\title{
Effect of Nurturing at Child Care Center on Gross and Fine Motoric, Language and Social Development in Children Aged Under Five Years in Ungaran Barat Subdistrict, Ungaran
}

\author{
Risma Aliviani Putri'), Bhisma Murti' ${ }^{1}$, Dono Indarto²) \\ 1)Masters Program in Public Health, Sebelas Maret University \\ 2)Faculty of Medicine, Sebelas Maret University, Surakarta
}

\begin{abstract}
Background: Child development is influenced by several factors including parenting style, active learning, and physical need fulfillment. It is generally recommended that nurturing is provided by parents, namely parenting. Because of some constraints, however, some parents are not able to nurture. Child care center (Taman Pengasuhan Anak) is an alternative way of child nurturing. This study aimed to analize the effect of parenting style, active learning, and need fulfillment on gross and fine motoric development, as well as language and social development at child care center.

Subjects and Method: This was an analytic observational study with retrospective cohort design. This study was conducted in Ungaran Barat Subdistrict, Ungaran, Central Java. A sample of 138 children under five years old with their mothers was selected by fixed exposured sampling for this study. The exogenous variables included parenting style, active learning, and need fulfillment. The endogenous variable was child development, including gross and fine motoric development, language and social development. The parenting style was measured by questionnaire. An observation sheet was used to observe and document child's active learning at child care center. Denver Development Screening Test (DDST) was used to measure child development. The data was analyzed by path analysis model.

Results: Fulfillment of need had positive effect on child development, and it was marginally significant $(b=1.38 ; 95 \% \mathrm{CI}=-0.15$ to $2.91 ; \mathrm{p}=0.077)$. Children who were raised by democratic parenting style were more able to learn actively than those raised by non democratic parenting style, and it was statistically significant $(b=1.12 ; 95 \% \mathrm{CI}=0.14$ to $2.11 ; \mathrm{p}=0.025)$. Children who were raised by democratic parenting style were more able to fulfill their need than those raised by non democratic parenting style, and it was statistically significant $(b=1.16 ; 95 \% \mathrm{CI}=0.002$ to 2.33; $\mathrm{p}=0.050)$. Children who actively learned were more able to fulfill their need than those who did not actively learn, and it was statistically significant $(b=1.81 ; 95 \% \mathrm{CI}=0.61$ to $3.01 ; \mathrm{p}=0.003)$.

Conclusion: There are effects of parenting style, active learning, and need fulfillment on child development, including gross and fine motoric development, as well as language and social development.
\end{abstract}

Keywords: parenting style, active learning, need fulfillment, child, development

\section{Correspondence:}

Risma Aliviani Putri. Masters Program in Public Health, Sebelas Maret University. Email: putririendera@gmail.com. Mobile: 085695222676.

\section{BACKGROUND}

Children under five years old is a common term for children who are between $1-5$ years old of age. This period of age is considered as an important period in the process of human development. Growth and development of every individual is distinct from one to another (Narendra, 2008). The growth and development during early childhood become the determinant of successful children growth and development in the subsequent periods. In this age, the development period occurs in a brief period of time and it will not happen again, 
therefore it is often addressed as the golden age.

Development is the improving ability of body functions and structures which are more complex. Development is the result of interaction between the maturity of central nervous system with the influenced organs such as neuromuscular system, speech, emotional and social functions, in which all of the functions play important roles in human life (Narendra, 2008). According to Berk (2005) the first year of a child's life will influence the child's development in the subsequent phase.

Children development consists of four aspects of development namely personal social, fine motor, gross motor, and language development. A child is already able to communicate since birth by crying, facial expressions and movements. Therefore, it is better to give parents the skills to improve their children development from birth.

In early childhood it is important to implement the proper nurturing process. Nurturing is a process of interaction between parents and children. In reality, nurturing is not only conducted by parents, but also by family and society. Parental loving nurturing, appreciating the potentials, giving optimum stimulations for all aspects of children development are the real answers for the growing of excellent generation in the future (Susanto, 2011).

When a family is no longer able to give the proper and adequate nurturing for the children, society tries to give it. Some cases in several countries illustrate problems faced by grownups as the care taker of children life when the family members are not available (Brooks, 2011). An under five years old child needs a place where he can find the proper nurturing while both parents and family are not able to give it, since the proper nurturing is needed to support the development of children under five years old.

Nurturing conducted by society or Child Care Center to be exact becomes an alternative for parents. A good Child Care Center will always demand parental consistent involvement in consultation, planning, implementation and evaluation of the program and activities that help children's development (Kemendiknas, 2011). Although nurturing in Children Care Center is not similar as they are taken care by their own parents however communication between parents and providers of the care centers still occurs in making any decisions (Barnardos, 2006).

Data from Ministry of Education and Culture (2014) shows that there are 502 Child Care Centers in Central Java with a total of 5,192 children to be taken care of, excluding unregistered Child Care Centers. The data show that Central Java has the greatest number of Child Care Centers among other provinces in Java island such as Jakarta 15, West Java 157, Banten 30, East Java 319 and Yogyakarta 219. It proves that the existence of Child Care Center is needed by parents for their children nurturing.

The result of an observation in one of the Child Care Centers in Ungaran, Semarang Regency showed that there were 31 children under five years old who were taken care of in that institution, and almost all of them were able to mingle well with their peers, able to communicate with their their peers and their caregivers as well as doing activities with the toys available, although not all of the toys were used. It was presumed from the observation that the number of the children under five years old who were taken care of in the Child Care Center, the environment of the Child Care Center, educative facilities and the limited number of caregivers drove a 
special attention in promoting the development of children under five years old.

This study aimed to analyzed the effect of nurturing in Child Care Center in West Ungaran Sub District, toward the development of personal social, fine motor, gross motor and language of children under five years old.

\section{SUBJECTS AND METHOD}

\section{Study design}

The study was an analytic observational study with retrospective cohort approach. Data collection was conducted in September to October 2016 located in Child Care Centers in West Ungaran Sub District, Semarang Regency under the working area of West Ungaran Community Health Center.

\section{Population and sample}

Targeted population of the study was children under five years old. The source population of the study was children under five years old who were cared for in Child Care Centers that adopted curriculum of Ministry of National Education, regular Child Care Centers, and taken care of by their parents. The number of population was 69. Sample was selected by using fixed exposure sampling technique that is a sampling method based on the exposure status of research subjects that is exposed or not exposed by factors which is predicted affecting an incidents.

\section{Variable}

Variables of the study were parenting style, active learning, physical need fulfillment, and development of children under five years old.

\section{Study instrument}

Data collection techniques used questionnaires, observation sheets, and DDST.

\section{Data analysis}

The data were analyzed by using path analysis, assisted by Stata 13 program.

\section{RESULT}

The characteristics of the study subjects for mothers and caregivers in West Ungaran area. Most mothers and caregivers (81.16\%) were $20-40$ years old. More than a half of the mothers and caregivers were High School/ Vocational High School graduates (50.72\%). Most of the children under five years old were 2 to 4 years old (94.2\%). The most children's age was between 2-3 years old (53.62 \%). Most children under five years old were female (53.62\%)

1. The characteristics of subjects of the study.

Table 1. The characteristics of subjects of the study

\begin{tabular}{|c|c|c|c|}
\hline Characteristics & $\bar{n}$ & $\%$ & Total \\
\hline \multicolumn{4}{|c|}{ Mothers' age (Year) } \\
\hline $20-30$ & 25 & $36.23 \%$ & \multirow{3}{*}{$100 \%$} \\
\hline $31-40$ & 31 & $44.93 \%$ & \\
\hline$\geq 41$ & 13 & $18.84 \%$ & \\
\hline \multicolumn{4}{|c|}{ Maternal Education } \\
\hline Elementary school & 7 & $10.14 \%$ & \multirow{5}{*}{$100 \%$} \\
\hline Junior high school & 17 & $24.64 \%$ & \\
\hline Senior high school & 35 & $50.72 \%$ & \\
\hline Diploma & 5 & $7.25 \%$ & \\
\hline Graduate & 5 & $7.25 \%$ & \\
\hline \multicolumn{4}{|c|}{ Children's age (year) } \\
\hline $2-3$ & 37 & $53.62 \%$ & \multirow{3}{*}{$100 \%$} \\
\hline$>3-4$ & 28 & $40.58 \%$ & \\
\hline & 4 & $5.8 \%$ & \\
\hline \multicolumn{4}{|c|}{ Children's sex type } \\
\hline Man & 32 & $46.38 \%$ & $100 \%$ \\
\hline Women & 37 & $53.62 \%$ & \\
\hline
\end{tabular}

\section{Bivariate Analysis}

Bivariate analysis explained about the effect of an independent variable toward one dependent variable. The method used was Chi-Square test.

Table 2 presented bivariate analysis on parenting style toward active learning $(\mathrm{OR}=32.5 ; 95 \% \mathrm{CI}=1.45$ to $727.58 ; \mathrm{p}=$ o.001). It showed that there was no correlation between parenting style and active learning. 
Table 2. Chi square test on parenting style toward active learning of children under five years old

\begin{tabular}{|c|c|c|c|c|c|c|c|c|}
\hline \multirow{3}{*}{ Parenting style } & \multicolumn{4}{|c|}{ Active Learning } & \multirow{3}{*}{$\mathbf{O R}$} & \multicolumn{2}{|c|}{$95 \% \mathrm{CI}$} & \multirow{3}{*}{$\mathbf{p}$} \\
\hline & \multicolumn{2}{|c|}{ Less Active } & \multicolumn{2}{|c|}{ Active } & & Lower & Unper & \\
\hline & $\mathbf{n}$ & $\%$ & $\mathbf{n}$ & $\%$ & & & & \\
\hline Non democratic & 1 & $(1.45 \%)$ & 1 & $(1.45 \%)$ & 32.5 & 1.45 & 727.58 & 0.001 \\
\hline Democratic & 2 & $(2.9 \%)$ & 65 & (94.2\%) & & & & \\
\hline
\end{tabular}

Table 3 presented bivariate analysis of parenting style toward need fulfillment. There were correlation between parenting style toward need fulfillment $(\mathrm{OR}=1.05 ; 95 \% \mathrm{CI}=$ 0.99 to $1.11 ; \mathrm{p}=0.688$ ), but statistically were

Table 3. Chi square test on parenting style toward need fulfillment and active learning of children under five years old

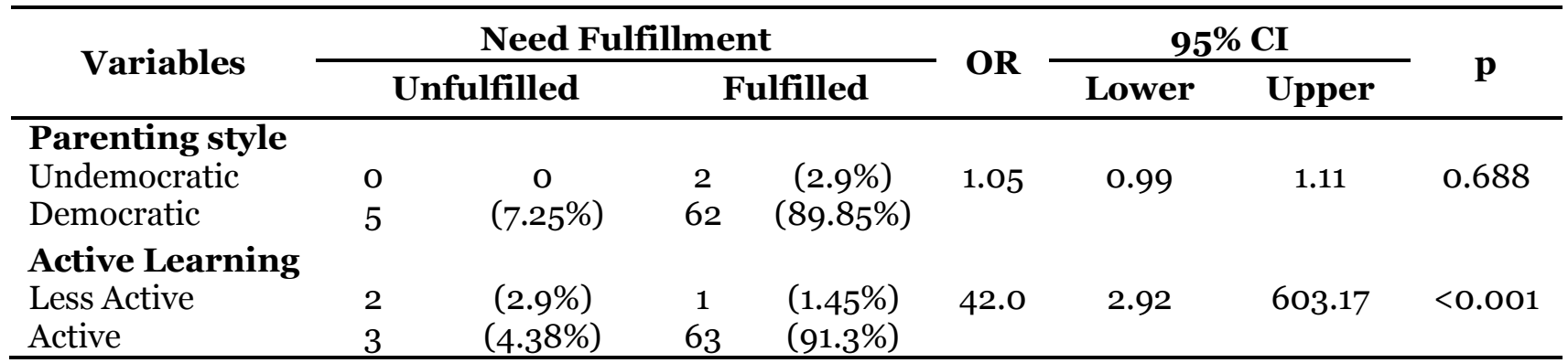

Table 4. Chi square test on need fulfillment toward development and parenting style of children under five years old

\begin{tabular}{|c|c|c|c|c|c|c|c|c|}
\hline \multirow{2}{*}{ Variables } & \multicolumn{4}{|c|}{ Development } & \multirow[b]{2}{*}{ OR } & \multicolumn{2}{|c|}{ CI 95\% } & \multirow[b]{2}{*}{$\mathbf{p}$} \\
\hline & & lbious & & Normal & & Lower & Upper & \\
\hline Need fulfillment & & & & & & & & \\
\hline Insufficient & 3 & $(4.38 \%)$ & 2 & $(2.29 \%)$ & 17.7 & 2.38 & 131.92 & $<0.001$ \\
\hline Sufficient & 5 & $(7.25 \%)$ & 59 & $(85.51 \%)$ & & & & \\
\hline Parenting style & & & & & & & & \\
\hline Non democratic & 1 & $(1.45 \%)$ & 1 & $(1.45 \%)$ & 8.57 & 0.48 & 152.73 & 0.085 \\
\hline Democratic & 7 & $(10.14 \%)$ & 60 & $(86.96 \%)$ & & & & \\
\hline
\end{tabular}

Table 4 shows the correlation between need fulfillment and development of children under five. It obtained the value of $\mathrm{OR}=17.7 ; 95 \% \mathrm{CI}=2.38$ to $131.92 ; \mathrm{p}<0.001$ that showed a significant correlation. Bivariate analysis between parenting style and development of children under five obtained the value of $(\mathrm{OR}=8.57 ; 95 \% \mathrm{CI}=$ 0.48 to $152.73 ; \mathrm{p}=0.085)$ that showed parenting style increased by 1.14 times the development of children under five however the increase was not significantly different.

\section{Path Analysis}

Table 5 showed $\mathrm{AIC}=221.09, \mathrm{BIC}=236.73$. The indicators presented that the smaller AIC and BIC values were, the more significant the correlation would be. Table 3 showed the likelihood $=-103.55$, meant that there was the effect of parenting style, active learning and physical need fulfillment toward development. 
Table 5. The result of path analysis on the effect of parenting style, need fulfillment, active learning through Child Care Center toward the development of children under five years old

\begin{tabular}{|c|c|c|c|c|c|c|}
\hline \multirow[t]{2}{*}{ Dependent Variable } & & \multirow[t]{2}{*}{ Independent Variable } & \multirow{2}{*}{$\begin{array}{l}\text { Path } \\
\text { Coef }\end{array}$} & \multicolumn{2}{|c|}{ 95\% CI } & \multirow[t]{2}{*}{$\mathbf{p}$} \\
\hline & & & & Lower & Upper & \\
\hline \multicolumn{7}{|l|}{ Direct Effect } \\
\hline Normal Development & $\leftarrow$ & Sufficient need fulfillment & 1.38 & 0.15 & 2.91 & 0.077 \\
\hline \multicolumn{7}{|l|}{ Indirect Effect } \\
\hline Active learning & $\leftarrow$ & Democratic parenting & 1.12 & 0.14 & 2.11 & 0.025 \\
\hline Sufficient need & $\leftarrow$ & Democratic parenting & 1.16 & 0.002 & 2.33 & 0.050 \\
\hline fulfillment & $\leftarrow$ & Active learning & 1.18 & 0.61 & 3.01 & 0.003 \\
\hline \multirow{2}{*}{\multicolumn{7}{|c|}{$\begin{array}{l}\log \text { likelihood }=-103.55 \\
\mathrm{~N} \text { observation }=138\end{array}$}} \\
\hline & & & & & & \\
\hline$=221.09$ & & Information: & & & & \\
\hline$=236.73$ & & $\leftarrow$ associated & & & & \\
\hline
\end{tabular}

\section{DISCUSSION}

Need fulfillment in this study was physical need fulfillment in a form of the fulfillment of nutrition and rest also health of children under five. The study result showed that needs fulfillment had the possibility to improve the development of normal children under five years old. A study by Dewi (2011) states that children with good nutritional status will have normal development compare to children with less nutritional status who will have deviant development. The similar argument is also stated by Liu (2013) that food providing to infants and children can affect their growth and development, providing healthy food since their infancy will affect their behavior in their childhood and adulthood.

Need fulfillment especially nutritional sufficiency is seriously needed especially during the golden age (1-5 years old). In the study most of the study subjects were between 2-4 years old of age therefore need fulfillment on the nutrition is very important. Insufficient food intake on the children can lead to developmental disorder. It is because nutrition has direct effect on neurotransmitter which is important in delivering messages from body to brain (Ross, 2010). Insufficient nutrition will lead to less optimum development of children under five years, nutritional sufficiency leads to higher normal gross motor development than children whose energy intake is sufficient with not normal and dubious gross motor development (Sani, 2014).

In addition to nutrition sufficiency, the need for rest for children under five is one of the needs to be fulfilled. Lack of rest/sleep on children under five gives impact to the less optimum cognitive development of children under five (Kamp et al., 2015). Insufficient rest on children under five will lead to problems in daily activities, it is possible since the quality of good sleep is important for the maturity of nerves and synaptic. Lack of sleep and rest will make children easily becoming tired, less energetic and lethargic to do activities. Lack of rest problem on early childhood will not only give impact to children's current condition but also will give impact to behavior and attention development, and emotional problems that can generate academic decline (Ravid et al., 2009).

Health factor can be in a form of disease prevention, and one of the most important is regular and scheduled vaccinations. After 1 year old, the vaccination 
given is the repetition. Vaccination is useful to strengthen children's immune against a certain disease. Repeated vaccinations among others are measles and polio at the age of 4-6 years. In addition to repeated vaccinations, there are also hepatitis $A$ and typhoid vaccines at 2 years old (Kemenkes RI, 2013).

The result of the study was children under five who were nurtured democratically had the more possibility to actively learn compared to children who were nurtured undemocratically. Good parenting style for children under five is democratic parenting since it is in accordance with the development stage. The parenting style sets a clear expectation and high standard as well as monitor children's behavior, by using logic discipline. They also encourage children to make decisions and learn from their experience. Children who are parented with democratic parenting tend to be socially competent, responsible and independent (Israfil, 2015).

In addition democratic parenting do not give pressure to children, give more independence however it is still under control therefore children are more active in academic, persevering, and full of confidence (Bibi et al., 2013).

Democratic parenting conducted by parents is affected by some factors among others are mothers' or caregiver's educational background and age. The educational background of most mothers was high school/ vocational high school and it became one of the factors that promoted. A study by Kharmina (2011) states that mothers with high school educational level are likely to be $74 \%$ better in parenting their children compare to mothers with secondary level of education. The higher education level of mothers or caregivers the better option of parenting style will be selected. Beside education, the factor of mothers' age also affects the parenting style. Mothers who are not too young or too old, between 20 to 40 years old, tend to have distinctive point of view about good parenting for their children which is not authoritative however they do not set their children free too much and of course they consider their own parenting experiences they underwent themselves.

Children is different from adult in term of characteristics. Children learn through playing and children learn naturally. Children's learning characteristics is a phenomenon that should be understood and used as the reference in planning and implementing education in early childhood (Masitoh, 2009).

The best parenting for children under five years old should be conducted by parents, since children will feel the attachment more with their parents especially a child will have their own time to learn. However, it is not a mistake if a child is put under the care of Child Care Center if parents are not able to do it themselves, providing that parents select Child Care Centers that provide good parenting with positive impact for their children growth and development. In Child Care Center with certain curriculum, children will learn from concrete to abstract matters, they learn through social interaction and a child is an active learner (Kemendikbud, 2013).

In learning process children are the subjects of the activity and the educators are the facilitator. Children own big curiosity, have a lot of ideas, and cannot stand still for long period of time. If we let children play various toys with numerous varieties of methods, and give time for children to recognize their environment with their own way then children inevitably will be active (Kemdikbud, 2013).

The result of the study showed that the needs of children under five years old 
who were nurtured democratically are likely to be more fulfilled than those who were nurtured undemocratically. Needs fulfillment that is sufficient is very important not only for children's body immune but also able to optimize children's physical and mental development also the well being of children's health condition. Good parenting give contribution for the welfare and happiness as well as the good quality of life of children entirely, because if the parenting is insufficient, especially the assurance on children's food and health, it can be one of factors that lead to malnourished children (Masithah, 2005). Parenting, health and food in the first year of a child's life is very important for the child's development. Insufficient parenting is an indirect cause of malnutrition (Santoso, 2004). Sulistiyani (2010) conveys that parenting style significantly affects the emergence of nutrition problems on children. Parenting style which is very strict or very loose will affect on the lack of nutrition fulfillment of children under five. Authoritarian parenting style contains a lot of pressure, meanwhile permissive parenting style gives very low monitoring (Reicks et al., 2015).

Parents involvement in the parenting becomes complex and multidimensional in which their emotion, and personality contribute in the children's quality of sleep (Sadeh et al., 2009). A child will feel comfortable and peaceful if they sleep next to someone who are considered emotionally close. Parents, especially mother gives the most comfortable place when a child is sleeping. By her side a child will feel more peaceful and comfortable therefore the child can sleep in longer period of time.

A study result shows that active learning affects the needs fulfillment. It is possible since need fulfillment either physiology or psychology, possesses impulse in a form motivation within each individual, so that the individual will exhibits active effective attitudes as well as certain emotion in attaining the need contentment, both physiological and psychological, in which the motivation for the needs fulfillment emerges (Feist, 2010).

Murray states that the occurrence of needs is concluded from the effect or final result of behavior, pattern or related special behavior, emotional expressions, or certain feelings, and contentment expression. The parts are elements of a child who are active in learning process.

The result of the study showed that children under five years of age who actively learned are likely to be more fulfilled compared to those who did not actively learn. Arifin (2015) states that children's appetite depends also on their activities and health condition. It confirms that the more active a child under five years of age, the bigger nutrition sufficiency she needs. An active child will easily gets hungry and often asks for and seek for food.

An active child is considered healthier since she often conducts activities in her daily life therefore she has fitter and healthier body. Active learning involves children directly in the learning process, the experience to directly get in touch with people, objects, ideas and events. Experiences on active learning will help children establish their knowledge such as: concept learning, ideas building, creating their own symbols and abstraction. In active learning there are facilitators who will observe the participation of the children. Here, the roles of parents, caregivers and teachers are very important as the facilitators.

The result of study showed that parenting indirectly affected the development of children under five years of age. It is in accordance with (Yulita, 2014) that there is a correlation between parenting 
style and the development of children under five years of age. The development of children under five of age is affected by several factors, parenting style is only one of the factors. Factor that directly affects the development of children under five years of age is physical need fulfillment those are the fulfillment of nutrition sufficiency, rest and health. In daily life the three factors should contribute equally, since if one of them is inadequate therefore it will give impact to the other factors. Need fulfillment which is sufficient will give impact to the optimum development of children under five years of age in accordance to their age.

It can be concluded from the result of the study that children under five years of age whose all needs are fulfilled develop normally. Children under five years of age who are nurtured democratically are more fulfilled in terms of physical needs. Children under five who actively learn are more fulfilled in terms of physical needs.

\section{REFERENCE}

Barnardos (2006). Parental Involvemental handbook for children provider. The National Children's Resource Centre.

Belsky J (2009). Effect of child care on: Give Parents real choice.Institute for the Study of Children, Families and Social Issues, Birkbeck University of London.

Berk L (2005). Child Development. United States of America: Pearson Education Inc.

Bibi F, Caundhy, Awan AE, Tariq B (2013). Contribution of Parenting Style in life domain of Children. IOSR Journal Of Humanities And Social Science (IOSR-JHSS) 12: 91-95.

Brockman, Jago R, Fox RK (2010). The contribution of active play to the physical activity of primary school children: Elsevier Journal Prev Med 51(2).

Brooks J (2011). The Process of Parenting. Yogyakarta: Pustaka Pelajar.

Christina F (2015). From Dawn till Dusk Implications of Full-Day Care for Children's Development. University of St. Gallen and CESifo.

Dewi A, Arini S (2011). Hubungan status gizi dengan perkembangan anak usia 3-5 tahun (Skripsi). Akademi Kebidanan Mamba'ul 'Ulum Surakarta.

Fedora D (2012). Pengaruh gaya Pengasuhan orang tua terhadap karakter disiplin, tanggung jawab dan penghargaan pada anak usia middle chilhood. Fakultas Psikologi. Universitas Indonesia.

Fitriani (2012). Hubungan pola asuh ibu dengan tingkat perkembangan personal sosial anak usia pra sekolah (Skripsi). Universitas Negeri Yogyakarta.

Ginintasari R (2009). Kontribusi Pola Pengasuhan Orang Tua Terhadap Perkembangan Kemandirian dan Kreativitas Anak (Skripsi). Fakultas Psikologi.

Handayani S (2011). Pola Pengasuhan Anak pada Taman Pendidikan Anak Aisyiyah Wilayah Baru.portalgaruda.

Hartawan B (2008). Karakteristik Tumbuh Kembang Anak di Tempat Penitipan Anak Werdhi Kumara 1, Kodya Denpasar. Jurnal Sari Pediatri (10): 134-138.

Hasan A (2008). Kamus Besar Bahasa Indonesia, Jakarta: Gramedia.

Israfil (2015). Hubungan pola asuh orang Tua dengan perkembangan anak usia Prasekolah (Tesis). Psychology Forum UMM, ISBN.

Jonathan S (2007). Analisis Jalur untuk Riset Bisnis dengan SPSS, Yogyakarta: Andi Offset. 
Kamp I, Waye K, Gunarson A (2015). The Effects of Noise Disturbed Sleep in Children on Cognitive Development and Long Term Health. Journal Child Adolesc Behaviour 3:1.

Karmima N (2011). Hubungan antara tingkat pendidikan orang tua terhadap orientasi pola asuh. Universitas Negeri Semarang.

Kemendikas (2011). Petunjuk Teknis Penyelenggaraan Taman Penitipan Anak, hal 1-33. Jakarta.

Kemendikbud (2014). Statistik Pendidikan Anak Usia Dini. Jakarta.

Liu Y, Stein M (2013). Feeding Behaviour of Infants and Young Children and Its Impact on Child Psychosocial and Emotional Development childhood. Encyclopedia on early Development.

Muaris H (2006). Sarapan Sehat Untuk Anak Balita. Jakarta: PT Gramedia Pustaka Utama.

Murti B (2013). Desain dan ukuran sampel untuk penelitian kuantitatif dan kualitatif dibidang kesehatan. Yogyakarta: Gadjahmada University Press.

Narendra M (2008). Tumbuh Kembang Anak dan Remaja. Jakarta: CV Agung seto.

Nikmawati E (2007). Tumbuh kembang pada anak usia dini.

Noor J (2013). Metodologi Penelitian. Jakarta: Kencana Prenada Media Group.

Patmodewo S (2008). Pendidikan Anak Usia Dini. Jakarta: Rineka Cipta.

Rahayu S (2013). Pertumbuhan dan Perkembangan Balita di Posyandu Surakarta. Poletekes Solo.

Reick, Banna, Cluskey (2015). Influence of Parenting Practices on Eating Behaviors of Early Adolescents during Independent Eating Occasions: Impli- cations for Obesity Prevention. Oregon State University.

Ross A (2010). Nutrition and its effect on academic performance how can our schools improve. Nutrition and Academic Performance Journal.

Sadeh, Tikptzky, Scher (2009). Parenting and Infant Sleep. Elsevier Journal. Sleep Medicine Reviews 14: 89-96.

Soetjiningsih (2012). Tumbuh Kembang Anak. Jakarta: EGC.

Susanto A (2011). Perkembangan Anak Usia Dini. Edisi 1. Jakarta: Prenada Media Group.

Sutomo B, Anggraini DY (2010). Makanan Sehat Pendamping ASI. Jakarta: Demedia.

Sulistyawati A (2014). Deteksi Tumbuh Kembang Anak. Jakarta: Salemba Medika.

Utami R (2008). Pengaruh tingkat pendidikan dan tipe pola asuh orang tua terhadap perkembangan psikososial anak pra sekolah (3-6 tahun) (Skripsi). Universitas Negeri Sebelas Maret Surakarta.

Vidyaniningrum (2013). Praktik Pengasuhan Anak pada Keluarga Petani Peserta Bina Keluarga Balita (BKB) Melati 3 Di Desa Nguken, Bojonegoro (Skripsi) Universitas Negeri semarang.

Wibowo A (2012). Proses pengasuhan ibu Bekerja (Skripsi). Fakultas ilmu budaya dan Humaniora. Universitas Islam sunan Kalijaga Yogyakarta.

Yulita R (2014). Hubungan pola asuh orang tua terhadap perkembangan balita (Skripsi). Fakultas Kedokteran dan Ilmu Kesehatan. Universitas $\mathrm{Mu}-$ hamadiyah Surakarta. 